\title{
Myopic PPPs: Risk allocation and hidden liabilities for taxpayers and users
}

\author{
Germà Bel, Paula Bel-Piñaña \& Jordi Rosell \\ (Forthcoming Utilities Policy)
}

\begin{abstract}
Drawing on evidence from three case studies, we show how the State's Financial Liability has worked in assigning risk in large PPP contracts in Spain. Project failure and the concessionaires' bankruptcy have resulted in the government having to assume heavy financial obligations, which have ultimately been absorbed by taxpayers and users. In contrast, Spain's leading construction companies, which were also major investors in the concessionaires, have been able to minimize their risk. Myopic PPPs have been entered into based on the transference of liabilities to taxpayers and users, and the, consequent, minimization of risks for the main private investors.
\end{abstract}

Keywords: Public-Private Partnerships; Concessions; Infrastructure projects; Transportation; Energy

\section{Introduction}

A public-private partnership- PPP - is a long-term contract ${ }^{1}$ between public and private parties, the aim of which is to deliver infrastructure or facilities projects in a specific economic sector (Albalate, Bel and Geddes, 2017). Although a fairly broad concept, PPPs include two key characteristics: First, the transfer of risk from the taxpayer to the private partner(s) (Engel, Fischer and Galetovic, 2014) following the payment of a risk premium by the government; and, second, the bundling under the contract of various tasks. While the institutional literature on PPPs tends to consider the undertaking of different tasks as the defining characteristic of such contracts (e.g. Hodge, Greve and Boardman, 2010), industrial organization scholars take a more restrictive approach, requiring the bundling of construction and operation under the same contract for it to be considered a PPP (Martimort and Pouyet, 2008; Bennett and Iossa, 2006). Despite these discrepancies, risk sharing between the taxpayer and the private partner - and bundling can be considered the two distinctive features of PPPs (Iossa and Martimort, 2015).

One of the advantages stressed in the economics literature (e.g. Engel, Fischer and Galetovic, 2014) of using PPPs with user payments is that they can help prevent the building of 'white elephants'; that is, public investment projects with negative social returns (Robinson and Torvik, 2005). Indeed, white elephants are a real problem in many countries, having especially significant effects on transport infrastructure. This problem is particularly acute in Spain, a country where the excess infrastructure supply (measured as the mismatch between supply and demand) has been shown to be greater than in any other comparable European country (Albalate, Bel and Fageda, 2015). However, and it is this paradox that this paper seeks to understand, Spain is precisely the European country in which most frequent use has been made of PPPs (with revenues based on user payments) to develop and manage large infrastructure, above all in sectors such as those of the motorways (Albalate, 2014) and water distribution (Bel, 2006).

1 We focus our attention here on contractual PPPs. Note that another type of PPP exists, namely institutionalized PPPs or mixed firms, in which the government and private partner have joint ownership of the firm used to develop the infrastructure or deliver the service. See Cruz and Marques (2011) for a more complete explanation and discussion of institutionalized PPPs. 
Among the guarantees that the Spanish legal framework and specific PPP contracts contemplate for the promotion of PPPs, the most important is the State's Financial Liability (Responsabilidad Patrimonial de la Administracion). This regulation provides for public compensation in case of the early rescission of the concession, owing to the bankruptcy of the concessionaire. Under the terms of the State's Financial Liability, a government guarantees to pay the concessionaire the amount - excluding depreciation - of (1) the investments made for the expropriation of land, and (2) the cost of the execution of construction works and the acquisition of other assets necessary for managing the facility or infrastructure. Usually, the amounts associated with the construction works is pledged in the financial contracts, and serves as a guarantee or public insurance for third parties providing funding. The State's Financial Liability also prevents the public sector from taking over the assets for the operation of the infrastructure or facility for free. However, this implies the direct transfer of the financial risk to taxpayers. The guarantee provided by the State's Financial Liability encourages private investors to undertake investments of uncertain profitability - indeed, these same investors would be much more reluctant to enter in to PPPs in the absence of the State's Financial Liability.

Our first aim with this research is to test the theoretical prediction by Engel, Fischer and Galetovic (2014) that using PPPs with user payments can help prevent the building of 'white elephants'. The methodology we choose to check such theoretical prediction is that of case studies. As explained in Gerring (2004:352), case studies are more appropriate particularly when useful variance is available only for a small set of units, as it happens in the policy area for which we conduct our research. Furthermore, our research has a disconfirmatory approach, and case studies are more useful to disconfirm than to confirm an inference (Gerring, 2007: 237). We also conform to the proposition by Gerring (2007) that for a case to be something broader than itself, the chosen case must be similar to a larger population. Indeed, the three cases we choose are representative of the entire population of PPP projects undertaken under the PPP-related legislation in Spain. Finally, it is worth noting that, besides testing above-mentioned prediction in Engel, Fischer and Galetovic (2014), a secondary aim of our research is to understand how casual mechanisms interact, ${ }^{2}$ making more likely the bankruptcy of public projects undertaken by means of a PPP.

Based on three case studies conducted in different sectors (motorways, railways and energy), this paper shows how the State's Financial Liability performs in assigning risks in PPP contracts and its effects on taxpayers and consumers. In the motorway and railway case studies, the concessionaires went bankrupt during the operational phase; in both instances, the main reason for bankruptcy was that actual demand was far below forecasts when the PPPs were awarded. In the energy case study, a submarine natural gas storage facility never came into service, owing to unexpected geological problems following its construction. In all three cases, the State's Financial Liability has involved massive financial transfers which have had to be shouldered by the taxpayer and the user.

Our analysis identifies relevant policy implications that emerge from the case studies. The fact that the Spanish government engaged in shortsighted PPPs, undertaken on the basis of overly optimistic demand forecasts, having neglected to undertake proper risk analyses (such as those related to geological conditions), transferred excessive risk onto the taxpayers and users. The latter have suffered heavy fallout as a result of the concessionaires' bankruptcy, while the interests of the construction firms (frequently also the holders of the corresponding concession) and financial investors have been fully protected. A more balanced approach to PPP risk transfers in Spain would have prevented the undertaking of these white elephants, and would have avoided exacerbating the mismatch between supply and demand.

${ }^{2}$ We are grateful to a referee for this valuable insight. 


\section{A typology of risks in PPPs}

Defining the risk associated with PPPs has been the object of extensive analyses, and leading international organizations, including the OECD (2012) and the World Bank (2015), have published comprehensive reports on this subject. Additionally, discussions of the nature of this risk and the risk allocation between partners in specific sectors have been undertaken in Albalate et al. (2015) for roads, Cabrera, Suárez-Alemán and Trujillo (2015) for ports, Cruz and Marques (2011) for airports, and Marques and Berg (2011) for water, among others. In this section, we briefly present a typology of the risks associated with PPPs, and discuss the appropriate allocation of risks between public and private partners, in the different sectors in which PPPs are used. It is worth emphasizing that it is consensual knowledge that the risks ought to be allocated to the party best equipped to manage them. To undertake this discussion, we distinguish between the different phases in the project when the risks can emerge: i.e. during construction and during operation.

\subsection{Construction phase}

In the construction phase, four types of risk can be identified: (1) risk from land expropriation; (2) risk from permits and licenses; (3) project design risk; and (4) geological risk.

The risk associated with expropriation concerns the acquisition of the land on which the project is to be developed. Even when the government is responsible for managing the acquisition of the land, it is the private partner that usually has to meet the costs. In some cases, however, it may well be that cost deviations (with respect to official forecasts) arise; yet, the private partner has no control over most of these circumstances (e.g. judicial decisions regarding land value). In such a scenario, it is recommended that the public sector assume the risk. Indeed, this risk is most commonly mitigated by setting a percentage cost deviation threshold, above which the administration absorbs the cost. An extreme solution in this regard is the one implemented in recent Chilean regulations, establishing that the government provide the lands and pay for their cost (Albalate et al., 2015).

The risk associated with permits and licenses concerns the delay in obtaining the necessary authorizations to execute the work. Certificates accrediting a positive impact on the environment are typically the most important of those documents. Even though a government takes this responsibility seriously, the private sector will eventually manage to obtain the necessary authorization but, in the meantime, must absorb the corresponding risk. However, the private risk can also be mitigated (as above), by setting a percentage deviation threshold, within which the private partner assumes the cost overrun. Cost deviations above this threshold, attributable to delays in obtaining licenses and permits, are assumed by the government.

The risk associated with the project design concerns the possibility that a project might be modified during the execution of works due to (a) unexpected government requirements, or (b) unexpected circumstances or errors. In the first case, it is the government that has to absorb the risk, whereas, in the second case, the risk is transferred to the construction company responsible for executing the work, which in turn can mitigate the risk by taking out an insurance policy.

Unforeseen geological risks can result in major cost overruns, especially in the case of tunnels and other underground constructions. Geological studies are notoriously expensive and any deviations are associated with a very high risk. This risk can be transferred to the construction company responsible for executing the work, although on occasions it is shared with the government. 
All in all, the private partner is more able than the government to control risks during the construction phase, which favors transferring risk to the private partner. Exceptions can be made, however, when cost overruns are attributable to decisions taken by the government or other public institutions, above all as regards land valuation or changes to the project design. For this reason, it is common to introduce specific clauses in contracts providing guarantees for the private partner.

\subsection{Operational phase}

In the operational phase, four additional types of risk can be identified: (1) demand risk; (2) availability risk; (3) financial risk; and (4) risk of technological progress.

Demand risk is one of the most significant risks for any project, involving as it does uncertainty about the expected use of the infrastructure. This uncertainty can result in high volatility in the concessionaire's revenues, and create major problems when repaying its creditors and distributing profits among partners. Although private companies can predict the natural evolution of demand, many exogenous factors, including macroeconomic variables, urban development, land use, and competing projects, can influence actual demand. To mitigate this risk, several measures can be adopted, such as establishing a minimum income guarantee, increasing the concession period to restore the economic and financial balance, placing restrictions on competition, ${ }^{3}$ and/or devising flexible toll rates in relation to real demand.

The availability risk concerns the increase in infrastructure operating and maintenance costs due to improper service operation. As such, this risk should be borne by the private partner. However, if the service is modified owing to actions not directly attributable to the concessionaire, the government may authorize a price increase or an increase in the length of the concession, in order to restore the economic and financial balance.

A financial risk can occur when the net cash flow is insufficient to repay loans and the capital invested in the project. It is fairly common for a government to issue guarantees and debt capital to reduce a project's risk premium. However, this risk is usually borne in the main by the private partner. Fluctuations in exchange rates of projects funded on international markets are particularly complex issues, especially in developing countries. If the risk premium is very high, the administration can mitigate part of the risk by means of an exchange insurance, or another State guarantee. However, such guarantees have been notoriously harmful to public budgets.

The risk associated with technological progress is a contingency that has only recently been acknowledged. Its origins lie in the constant emergence of applications and tools that are adopted as technology progresses. The most common requirements a concessionaire needs to consider are revisions to and adaptations of the regulations of its facilities and security systems. These actions inevitably increase infrastructure operating and maintenance costs. The risk is typically assumed by the private sector. However, the government may authorize an extension of the concession period, especially when the reforms are attributable to changes in public safety requirements.

Finally, consideration needs to be given to non-commercial risks, that is, unforeseeable risks lying outside the control of the efficient management of the infrastructure. Because of their nature, the government is usually held responsible for this contingency, following the abovementioned criteria that the risks must be allocated to the party best suited to deal with them

\footnotetext{
${ }^{3}$ Note that placing restriction to competition has the effect of protecting the concessionaire from unexpected publicly sponsored new projects, which would detract demand from the concession.
} 
The main non-commercial risks are: factum principis, ius variandi and force majeure. The risk of factum principis occurs when the economic balance of the contract is substantially altered due to a government act, resulting in direct damage to the concessionaire. The risk of ius variandi is the right of the administration to modify unilaterally the contract without the consent of the concessionaire. In this case, the contract can incorporate various clauses that limit the number of modifications that the government may impose. If the number of modifications imposed by the administration exceeds a certain boundary, the concessionaire has the option to free herself of the contract. The risk of force majeure, that is, natural disasters and wars, is unpredictable. The government usually bears this risk, but it is also common practice that the concessionaire protects itself by means of private insurance.

\section{State's Financial Liability in Spanish legislation on public contracts and concessions}

A concession contract, particularly when it takes the form of a PPP, can be expected to present one essential characteristic - namely, the transfer of an economic risk to the concessionaire. This means that, under normal operating conditions, the private party has no guarantee it will recoup the investments made and costs incurred in operating the concession. However, Spanish regulations governing concession contracts have regularly overlooked this key principle.

Preliminary regulations for concession contracts first appeared in Spain in relation to the first Railway Act of 1855. Articles 23 to 29 (and 39) of that Act established that, were the concessionaire to cease building or operating the concession, the government must organize up to three auctions. Each auction would take as its baseline a fraction of the costs incurred by the concessionaire: that is 100, 66 and 50\%, successively. If, after the three auctions, the concession had still not been awarded to a new company, the government would take over the concession at no cost. With only minor changes, this was to be the regulation governing the bankruptcy of concessionaires for just over a century.

A fundamental change was made to this regulation in the mid-1960s. During that decade, the Francoist regime sought to promote private investment in the building and management of a network of toll motorways, given the intense growth experienced by the economy (and, subsequently, by road mobility). ${ }^{4}$ Against this backdrop, Decree 923/1965 (Law of Public Sector Contracts) was passed. The new Decree recognized the right of the concessionaire to be compensated for the investments made in case of bankruptcy. The Law of Public Sector Contracts passed in 1973 further clarified the State's liability regarding the bankruptcy of the concessionaire. After the return of democracy to Spain, this cost recovery guarantee for the concessionaire (and corresponding liability for the government) was maintained - even perfected - through successive changes of the legal framework for concession contracts, namely, the Law of Public Administration Contracts of 1995, and the Law for Public Sector Procurement of 2007. Later, a Royal Decree passed in 2011 consolidated further the norms contained in the aforementioned Acts. ${ }^{5}$

One of the reasons why national governments and legislators, particularly in Southern Europe, have opted to use concessions is that, in accordance with the European System of Accounts (ESA 1995 and ESA 2010), the contracts do not have to be included in the national

\footnotetext{
4 An analysis of why the Spanish government chose to use private companies to develop the toll motorway network (while other countries such as France and Italy had chosen government owned companies) can be found in Bel (1999).

${ }^{5}$ See Albalate et al. (2016) for a detailed analysis of the evolution of the State's Financial Liability in Spanish legislation.
} 
accounts of budgetary deficits and debt. The EU institutions had been long aware of this issue, but paid little attention to it as was a matter of potential conflict with its Member States. Finally, Directive 2014/23/EU of the European Parliament and of the Council of 26 February 2014 on the award of concession contracts, passed in 2014, clarified the definition of risk transfer in concessions, indicating that a concession could be awarded only when the operational risk was fully transferred to the private contractor. Art. 5 of the Directive states:

"The award of a works or services concession shall involve the transfer to the concessionaire of an operating risk in exploiting those works or services encompassing demand or supply risk or both. The concessionaire shall be deemed to assume operating risk where, under normal operating conditions, it is not guaranteed to recoup the investments made or the costs incurred in operating the works or the services which are the subject-matter of the concession. The part of the risk transferred to the concessionaire shall involve real exposure to the vagaries of the market, such that any potential estimated loss incurred by the concessionaire shall not be merely nominal or negligible."

According to recital 18 in the preamble to the Directive, this means that a concession cannot be awarded if the contracting authority relieved the economic operator of any potential loss, "by guaranteeing a minimal revenue, equal or higher to the investments made and the costs that the economic operator has to incur". Thus, if operational risk is not transferred, if the state retains operational risk by means of guarantees (such as the State's Financial Liability), a service contract must be made, instead of a concession.

The EU Directive clearly contradicts current Spanish legislation on the transfer of operational risk and State's Financial Liability in relation to concessions. In this respect, article 51.1 of the Directive stated that it should be transposed into national legislation no later than 18 April 2016. But Spain has yet to comply. The Spanish government claims that the Directive could not be transposed because, between January and October 2016, the Spanish Congress failed to appoint a new government. However, in September 2015 the Spanish legislator reformed the Spanish law of public contracts, but avoided the transposition of the Directive. Yet, on 29 November 2016, the government sent a bill to the Spanish Congress providing for the transposition of the Directive (in Final Provision Ninth, numbers 8 to 11), but no specific date has been fixed for its reading. Once the bill is enacted, the State's Financial Liability will be extinguished (without retroactive effect) from Spain's legal regulations governing public contracts and concessions.

\section{Three cases of concessionaire bankruptcy and activation of State's Financial Liability}

We have chosen the cases analyzed in this section because we can describe systematically all three with the same procedure, and because they represent different sectors affected by the Spanish legislation. Note that because there is no temporal variation, and also because there is no difference between Spanish PPPs regarding the application of the State's Financial Liability, natural experiments or quasi-experiments are far from being applicable to isolate the true causal effect in our context. ${ }^{6}$ In all three cases, we have collected information from legal provisions, firms' reports, firms' press releases, media news, and from books and articles published on specific details for any of these concessions.

\subsection{Roads: Radial toll motorways}

${ }^{6}$ A very useful and widely known guide on case study design and methods can be found in Yin (1984). 
In May 1997, the Spanish Ministry of Public Works (Ministerio de Fomento) took the decision to promote the construction and operation of a set of toll motorways, most of them providing access to the city of Madrid. In total, five new radial (Madrid-centered) motorways were planned: (1) R-3 Madrid-Arganda, 34 km; (2) R-5 Madrid-Navalcarnero, 28 km; (3) R2 Madrid-Guadalajara, $81 \mathrm{~km}$; (4) R-4 Madrid-Ocaña, $88 \mathrm{~km}$; and (5) AP-41 Madrid-Toledo, $60 \mathrm{~km}$. According to the government, based on expectations of population growth and the location of new residential areas, these new toll motorways required urgent implementation in order to reduce future congestion on the existing six toll-free motorway access routes to Madrid.

Between October 1999 and February 2004, the state awarded concessions to build and operate these motorways to several concessionaires: Accesos de Madrid (R-3 and R-5, awarded for 50 years); Henarsa (R-2, awarded for 24 years); Autopista Madrid Sur (R-4, awarded for 50 years); and Autopista Madrid-Toledo (AP-41, awarded for 36 years). The initial equity share capital used in the financing structure of the concessions was quite low: $15 \%$ in the case of R-2; $20 \%$ in R-3 and R-5, and 25\% in R-4 and AP- 41 .

All the concessionaires were owned by shareholder groups, in which various construction companies owned the largest shares of capital. Banks and infrastructure operators (participating alongside the construction companies) owned the remaining shares. Figure 1 shows the distribution of share ownership within the concessionaires, highlighting the indirect participation of construction firms through their ownership of shares in the infrastructure operators. In Figure 1, the lowest section of each column shows the direct participation of construction firms, while the section second from the bottom shows the indirect participation of construction companies, through ownership of shares in the infrastructure operators (who would typically be industrial partners in the PPP). For example, in the case of concession R4 (Madrid Sur), construction companies directly own 35\% of this concessionaire, but indirectly they own an additional 55\% through their participation in the infrastructure operators. Similarly, other agents own 10\% of this concession, through their participation in the infrastructure operators.

The concession process was successful in all cases. Ambitious demand forecasts and cost expectations - which would soon reveal themselves to be highly optimistic - triggered this initial success. However, the key factor remained the inclusion of specific provisions guaranteeing the State's Financial Liability (which still formed part of the general legal framework) in each of the concession contracts.

Execution of the works was hampered from the outset by the increase in land expropriation costs. According to a report issued by the Association of Construction Companies and Infrastructure Operators (SEOPAN, 2014), the final cost rose to $€ 2,217$ million, six times higher than the $€ 387$ million expected, owing to judicial decisions regarding the value of the land. Other major cost overruns arose during the execution of the construction works, oscillating between 15\% in the case of R-3, and 31\% in the case of R-2 (Vassallo, Ortega and Baeza, 2012). For these reasons, the financial requirements increased for all the radial motorways, and the percentage of funding provided by the concessionaire shareholders (equity) fell even further below the initial percentages reported above. 
Figure 1. Share ownership in radial concessions

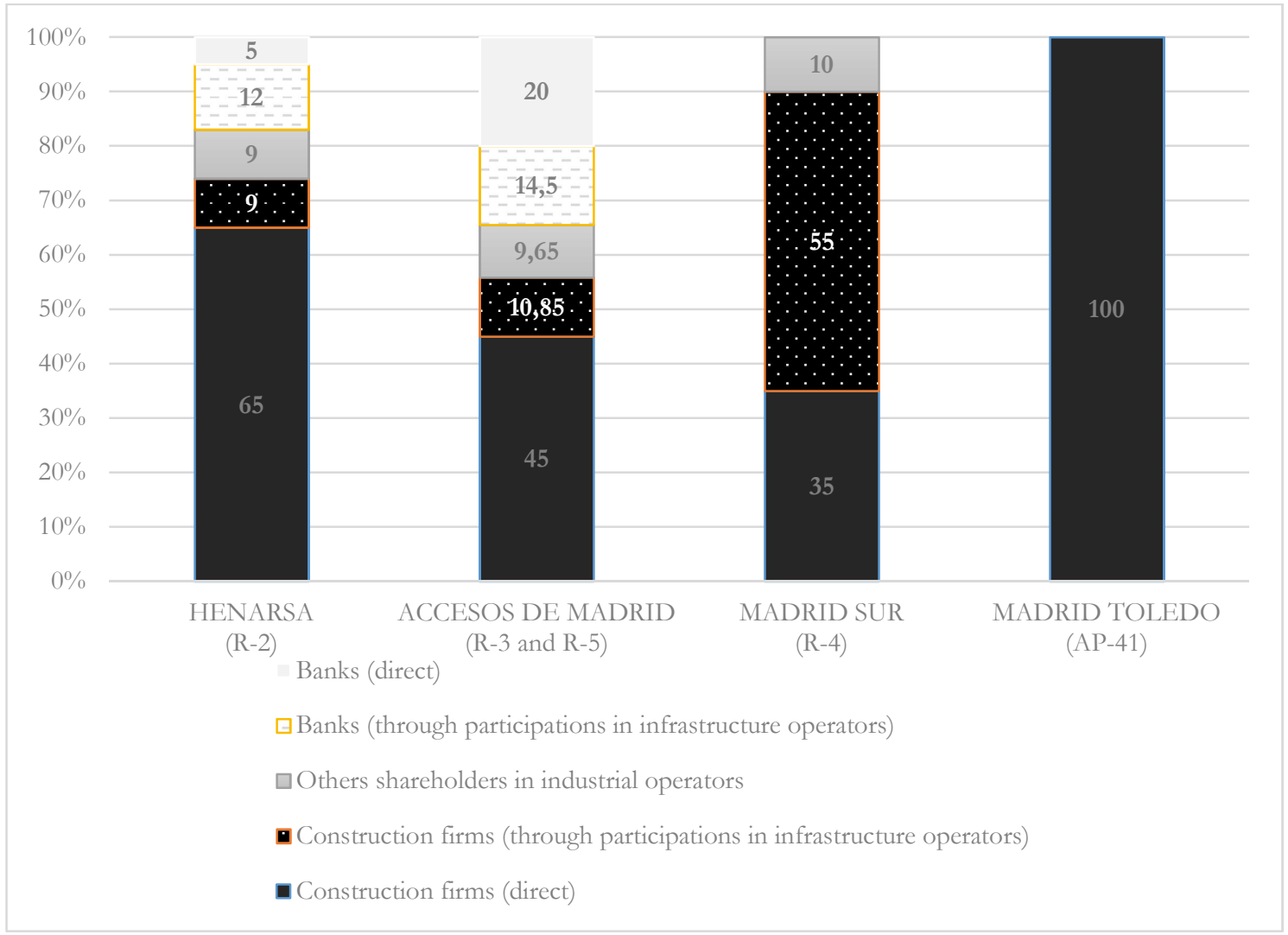

Source: Ministerio de Fomento (2016).

By the end of 2007, all five radial toll motorways were in full operation. However, the demand for the new infrastructure fell well below the estimates provided by the State. For instance, the average annual daily traffic (AADT) for the first year of operation of R-3 and R-5 was 10,438 and 6,793 vehicles, respectively, while the estimates provided by the State had been 24,023 and 16,364 vehicles. Note, in this regard, that the estimates made by the concessionaires themselves were usually similar to those provided by the government, and in some cases even more optimistic (Baeza and Vasallo, 2012). Even before the economic crisis of 2009, some concessionaires, most notably R-3, R-5, and R-4 reported markedly negative financial results. When the economic recession set in, the fall in traffic volume was devastating for the sector.

Given that the toll motorway concessionaires were unable to meet their debt obligations out of their toll revenues, form 2008 onwards the Spanish government and legislator began providing compensation: tariff increases, concession extensions, government loans that would form the capital of the concessionaires (participatory loans), etc. According to information recently made available by the Spanish government, ${ }^{7}$ around $€ 600$ million were transferred from the public budget to the concessionaires between 2008 and 2011, mostly in the form of participatory loans and subsidies to compensate for the fall in traffic volume.

Despite the financial and regulatory aid provided by the government, the concessionaires were unable to turn their financial position around. Between May 2012 and September 2013,

${ }^{7}$ El Mundo, 19/12/2016. El rescate de las radiales costará 50 euros por ciudadano.
htth:/ / www.elmundo.es/economia/2016/12/19/5856cd4dca47411e7a8b45bf.html 
all the radial toll motorway concessionaires filed for voluntary bankruptcy. At accounting year-end 2014, the ratio between their capital and investment costs had fallen significantly for all concessionaires: 11\% for R-2; $18 \%$ for R-3 and R-5; 14\% for R-4; and 20\% for AP41. Ultimately, the massive indebtedness of the concessionaires - due, in the main, to the limited weight of the shareholders' contribution - was the critical factor that made their survival impossible.

During 2014, the government's plan was to bail these companies out, if in exchange the creditors accepted a debt cut of around $50 \%$. By then, the accumulated debt of the four concessionaires and five concessions had risen to around $€ 2,200$ million (Ministerio de Fomento, 2016). ${ }^{8}$ The plan was based on the belief that the cost of a State-negotiated acquisition would involve a financial disbursement well below that which would result from the liquidation of the concessions, and the corresponding activation of the State's Financial Liability, which would mean the State taking over the concessionaires' accumulated debt. But, while Spanish financial institutions were open to exploring a possible deal with the government, the foreign financial entities and investment funds demanded activation of the State's Financial Liability, as in this way they were guaranteed the full recovery of their loans.

In the end, all government efforts to avoid activation of the State's Financial Liability were in vain, after the courts ordered the final liquidation of the R-3 and R-5 concessions in May 2016, and ordered their concessionaires to stop operations by October 2016. As might be expected, the government was unwilling to accept the closure of these two motorways (and the threatened closure of the remaining three), and announced it would take them over. At the time of writing, any decisions regarding the eventual costs the government will have to bear for assuming responsibility for this infrastructure are pending the termination of liquidation procedures. What is guaranteed - given the State's Financial Liability - is that the third parties which lent money to the concessionaires will recover their loans in full.

\section{2.: Railways: Perthus Tunnel}

In October 1995, Spain and France signed an international agreement to construct and operate the cross-border section of the high-speed rail (HSR) line designed to connect both countries across the Pyrenees. The Figueres-Perpignan line is $44.4 \mathrm{~km}$ long, of which 19.8 are in Spain and 24.6 in France (Observatorio hispano-francés de tráfico en los Pirineos, 2008). In terms of the public works involved, the most challenging section was the $8.3-\mathrm{km}$, twin-bore tunnel (Perthus Tunnel). To execute the work and operate the line, the participation of the private sector was foreseen. It was established that the concessionaire would receive subsidies from both States, as well as from the EU. In addition, the concessionaire was to be granted the right to charge a toll for traffic on the line (of mixed passenger-freight service). Furthermore, the concessionaire was granted a guarantee of a minimum threshold of traffic in the long-term.

The Spanish Government awarded a first concession on 23 February 2001. However, because of several procedural problems, as well as disagreements with the companies initially selected for the concession, the governments conducted a new tendering process in 2003. The TP Ferro group was eventually awarded the construction and operation of the HSR line in February 2004. At that time, TP Ferro was jointly owned by two private construction

\footnotetext{
${ }^{8}$ This was the most important of a set of actions to bail out a total of nine concessionaires and ten concessions, comprising the five radial toll motorways described here and additional toll motorways in Madrid, Valencian Community, and the Madrid-Levante Corridor. See, 20 Minutos, 25 March 2014, El Gobierno plantea asumir el $50 \%$ de la deuda de las autopistas en quiebra para rescatarlas http://www.20minutos.es/noticia/2095358/0/quita-deuda/bancos-estado/quiebra-autopistasrescate $/ \#$ xtor $=$ AD $-15 \& x t s=467263$
} 
companies, the Spanish ACS (50\%) and the French Eiffage (50\%). The concession term period was fixed at 50 years. Work began at the end of 2004, and was completed in February 2009.

The initial budget for the project was set at $€ 952$ million in 2003, but cost overruns led to a final cost of $€ 1,184$ million. The governments of Spain and France (and to a considerably lesser extent the EU) contributed $€ 636$ million in the form of direct grants, and $€ 44$ million as additional funding to ensure the viability of the concession. The other main items were the senior debt, which amounted to $€ 389$ million, and equity (the shareholders' contribution) which rose to $€ 51$ million. Funding was completed with some $€ 64$ million in loans and interest on participating loans, to constitute the equity of the company (Albalate et al., 2016). Note that the equity in TP Ferro represented less than $10 \%$ of total construction costs, and that more than $50 \%$ of the equity came from third party loans.

The process of granting and executing this line, achieved by means of a PPP agreement, was satisfactory in terms of the time schedules for the execution of the work, although cost overruns were significant. In contrast, its implementation proved deficient. The lack of connection with the domestic feeding HSR line - the Barcelona-Figueres line did not come into full service until 2013 - resulted in monetary compensation being paid and an extension to the concession (three additional years). Compensation could have been avoided with better coordination between the two projects, that is, by treating them as bundled segments. When the line did come into full service in 2013, it became clear that the demand forecast had been overly optimistic: while the concessionaire expected to run 24 trains a day on average in the first year of operation (and 30 in the long term), only 12 trains were put in service each day in 2014 (and that in the high season). The concession never enjoyed good financial health, and prospects remained far from bright.

In 2014, TP Ferro reported financial loses of $€ 112.8$ million, and at the end of that year the Spanish company ACS (the effective leader of the PPP vehicle) asked the Spanish government for further compensation. If compensation was not forthcoming, ACS suggested that the government take over the concession, in accordance with the contractual provisions on government liability.' Financial losses continued to accumulate over the following years, and TP Ferro proposed a plan to the Spanish and French governments, which included a new subsidy of $€ 80$ million and a 25 -year extension on the concession (until 2082). Both governments refused to provide additional compensation. In July 2016, the creditor banks and investment funds petitioned the jurisdictional judge to initiate liquidation of TP Ferro and to activate the State's Financial Liability, on the understanding that the governments would repay the debt, in accordance with the concession contract and general legal provisions.

In this regard, two points should be noted. First, although references to the fact that the project's risks be absorbed by the concessionaire appear throughout the concession agreement, clause 25 of this contract effectively recognizes the State's Financial Liability. Furthermore, clause 26 provides explicit details of how the amount of compensation should be determined. Second, given that TP Ferro established its social headquarters in Spanish Territory, all commercial and contractual matters that arise must be dealt with according to Spanish commercial and administrative law. This means, furthermore, that all issues not explicitly contemplated in the concession contract have to be dealt with in accordance with the laws and regulations of the states involved.

\footnotetext{
9 See El Periódico 18/12/2014. ACS renegocia la concesión del AVE en El Pertús por bajo tráfico. http://www.elperiodico.com/es/noticias/sociedad/acs-renegocia-concesion-del-ave-pertus-porbajo-trafico-3780792
} 
In September 2016, the partners of TP Ferro approved the liquidation of the company and the devolution of the concession to the Spanish and French governments. TP Ferro claimed $€ 450$ million euros from both governments, which is the theoretical accounting value of the assets, having discounted the public subsidies provided by the State authorities. This money would be dedicated in the main to paying off the creditor banks and investment funds. In December 2016, the concession was cancelled, and a new joint venture involving the two governments took over the infrastructure. The European Court of Arbitration is responsible for determining the compensation owed to TP Ferro in line with the concession contract signed in its day. The most likely outcome of this lengthy process will be that all third-party outstanding debt will be paid, and that the TP Ferro shareholders will fail to obtain any compensation for the equity they contributed.

\subsection{Energy utilities: The Castor natural gas storage project}

The Castor Project is a submarine natural gas storage facility off the east coast of Spain, capable of holding 1.3 billion cubic meters of gas, injected to a depth of 1750 meters under the sea. The storage facilities occupy a former underwater oil field, which Shell exploited between 1973 and 1989. However, by the nineties, the oil company realized that any further oil extraction in that location was no longer viable.

Spain's Hydrocarbons Law allows oil and gas extraction concessions to be converted into underground gas storage facilities. Moreover, gas storage plays a crucial role in balancing the country's gas supply and demand..$^{10}$ For reasons of supply security, EU Directives 98/93/EC and 2003/55/CE oblige Member States to maintain a minimum level of stocks of crude oil and/or petroleum derivative products. In adhering to these directives, Spain's storage capacities were increased dramatically, with substantial growth being recorded over the last sixteen years. In 2008, the Spanish Government published the 2008-2016 Electricity and Gas Sector Planning Report, in which a number of underground gas storage facilities were classified as 'urgent'. Storage capacity was developed in line with gas requirement forecasts, which were substantially higher than actual needs, as became quickly apparent following the reduction in demand attributable to the economic recession from 2008 onwards.

In January 2004, the company Escal UGS obtained a research permit to study the viability of the Castor project. Once the project was declared feasible, the Spanish government chose to promote the construction and operation of these facilities by means of a PPP concession contract. Royal Decree 855/2008 awarded Escal UGS the concession to build, operate and transfer the underground gas storage, with a fifty-year term of concession. Castor was to be operated as a regulated utility, and it was not expected to be exposed to either commodity price risk or market-based gas trading risk.

Escal UGS shareholders at the time were Castor UGS Limited Partnership, who owned a $33.3 \%$ of the concessionaire's capital, ${ }^{11}$ and the Spanish construction company, ACS, which owned two-thirds of the capital (66.7\%). Interestingly, ACS had increased its shareholding in Escal UGS from 5\% to $66.7 \%$ on December 21, 2007 (less than six month before the Royal Decree 855/2008). ${ }^{12}$ ACS had no previous experience in the oil and gas business, but

\footnotetext{
${ }^{10}$ Bradbrook (2014) provides a detailed explanation of the legal framework governing underground storage in Spain.

${ }^{11}$ Castor UGS is a subsidiary of the Canadian company, Dundee Energy (an oil and gas producer), who owned $74 \%$ of Castor UGS, while the remaining $26 \%$ was owned by minor investors.

${ }^{12}$ The same agreement foresaw that the Spanish company Enagàs (operator of the natural gas grid) would buy one-half of ACS shareholding (33.3\%), once the gas storage would begin operation. As we see below, this never occurred. See Agreement between Eurogas, ACS and Enagás for the Castor
} 
was a frequent builder of large public works, and also had proven experience in managing risk-free PPPs with the Spanish government, as demonstrated in the previous subsections describing PPPs in the road and railway sectors.

The building phase started soon after the concession was awarded, and most of the work was completed in 2012 and 2013. The construction phase was financed using $€ 209$ million of equity and a total debt of $€ 1.3$ billion, most of this being funded initially with a seven-year term loan provided by 19 banks. Debt represented more than $86 \%$ of the project's total initial costs, while equity amounted to a figure just below 15\%. As usual in public works of this nature, cost overruns occurred, which required a refinancing operation. This was conducted by means of a bond issue to the sum of $€ 1.43$ billion, and a $€ 200$ million letter of credit. In July 2013, the European Investment Bank and the European Commission hailed the Castor project as the first to be financed under the Europe 2020 Project Bond Initiative, in this instance, to the tune of almost $€ 1.7$ billion. ${ }^{13}$ The bonds were assigned a BBB+ credit rating from Fitch, and BBB from Standard \& Poor's, a duration of 21.5 years, and a coupon rate of $5.76 \%$. Among the investors, $61 \%$ of bonds were owned by institutional investors and just $3.9 \%$ by banks. This is often cited as an example of the fact that institutional investors are prepared to invest in long-term infrastructure projects.

From mid-September 2013, as cushion gas was being injected into the storage facility to prepare it for regular use, several hundred minor earthquakes rocked the Castor project area. On 1 October 2013, an earthquake registering 4.2 on the Richter scale was recorded. Residents reported tremors and damage to buildings in an area that had not experienced previous seismic activity. Escal UGS denied any link between the cushion gas injections and the earthquakes (Marsal, 2014), but operations were temporarily suspended. In the following months, the Spanish Institute of Geography (December 2013) and the Spanish Geological and Mining Institute (May 2014) concluded that the earthquakes had been provoked by the injections of cushion gas. These reports led to the suspension of all gas injections, and the cessation of the underground gas storage activities. The government declared the facilities associated with the terminated concession to be in hibernation (both as regards gas injection and extraction).

In July 2014, Escal UGS claimed it was contractually entitled to relinquish the concession and return it to the Spanish government. This in turn activated the State's Financial Liability, according to which the concessionaire should be compensated for all its investments in the project. Moving much faster than in similar disputes, on 3 October 2014 the Spanish government approved Royal Decree-Law 13/2014 accepting the relinquishment of the Castor Project. The Decree acknowledged the termination of the concession, and it reverted ownership of the associated facilities back to the State. The Spanish government determined compensation a total of $€ 1.46$ billion of compensation. In November 2014, Escal UGS already received $€ 1.35$ billion, equal to the net value of its investments, and these proceeds were used in the partial repayment of the $€ 1.41$ billion of outstanding bonds, and in paying off investment funds and creditor banks. ${ }^{14}$ It should be noted that, because Escal UGS was considered not to have undertaken a proper geological or environmental study of the area in

\footnotetext{
underground natural gas storage Project (December 21, 2007) http://www.grupoacs.com/adjuntos/2220 castor english.pdf (downloaded December 30, 2017) ${ }^{13}$ Clifton, Díaz-Fuentes, and Revuelta (2014) provide an exhaustive analysis of the role of the EIB in financing utilities over nearly half a century.

${ }^{14}$ It is worth noting that, on May 2015, Dundee Energy lodged a legal action challenging decisions by the board of directors of Escal UGS, who had decided to use the largest fraction of a new loan to repay shareholder loans, solely to ACS (Dundee Energy Limited, Report to Shareholders - May 2015) http://dundee-energy.com/pdfs/Letter-to-Shareholders.pdf , downloaded on January 30, 2017).
} 
which the facility was constructed, the government was called on (most notably by the Sindic de Greuges, 2014) to conduct an official inquiry before paying the compensation guaranteed by the State's Financial Liability.

The government took the decision not to use tax revenues to fund the payments due under the State's Financial Liability. Instead, it opted to place the burden on the consumers of natural gas, industrial as well as household. To this end, in November 2014, the government signed a deal with Enagas, the private company that owns the Spanish gas grid. Enagas was made responsible for the management of the facilities, and allocated collection rights from the gas system for a period of 30 years. During this period, Enagas will charge these costs to consumers by means of a surcharge on its tariffs. For example, in 2017, €96.4 million will be charged to natural gas consumers, of which $€ 16$ million correspond to the maintenance of the shut-down facilities, and $€ 80.4$ million to funding the State's Financial Liability. Furthermore, dismantling the facility will require an extra $€ 200$ million.

\section{Discussion}

The cases presented above illustrate three PPPs in three different sectors (motorways, railways, and energy) that were awarded during the last period of economic growth in the Spanish economy, and the subsequent collapse and bankruptcy of the concessions. All three cases have several traits in common: demand was heavily overestimated and costs overruns went beyond typical deviations for large projects suffering from overly optimistic forecasts. In some cases (i.e., radial motorways), this was attributable mainly to judicial decisions regarding land value that lay beyond the control of the concessionaires; in others (i.e., gas storage project), it was due to the lack of proper geological studies.

The cases have another common trait: because of the State's Financial Liability typically included under Spanish law, and specifically included in the three concession contracts, bankruptcy of the concessionaires requires the repayment of all third-party debts. As such, the concessionaires risk at most the equity contributed by their shareholders. That equity has, as we have shown, in all cases been a minor fraction of the total funds made available to pay for the construction works. In practice, the risk was transferred in almost its entirety to the taxpayers or to the users, depending on how the government opted to raise funds to meet the State's Financial Liability.

The reasons as to why the Government chose to undertake these highly uncertain, risk-laden projects lie beyond the scope of this study. However, Bel (2012) provides an analysis of the reasons why Spain's infrastructure policy - above all, in the transportation sector - has tended to generate an excess supply. Moreover, it is clear that the government opted to form PPPs to develop these projects primarily to escape the restrictions imposed by the European Union on public deficit and public debt, under the terms of the Maastricht Treaty and the European Monetary Union.

Of more interest to our discussion here is an understanding of the incentives that prompted the private partners to enter into these PPPs. On the one hand, the State's Financial Liability considerably reduced any financial risks derived from the concessions' operational risks. As we have seen, in practice, the risk assumed by the private partners was limited to the capital directly provided by the concessionaires' shareholders. In this regard, the fact that the large construction companies have been the sole, or at least, main owners of all concessions analyzed has played a key role (as shown in Table 1). The increase (right before the concession was awarded), and expected decrease (after the expected begin of operational service) of ACS' ownership in the Castor project concessionaire, clearly illustrates how construction interests have been crucial in these concessions. 
Table 1: Distribution of shares in the concessionaires.

\begin{tabular}{|c|c|c|c|c|c|c|}
\hline & \multicolumn{4}{|c|}{ Radial toll motorways } & \multirow[b]{2}{*}{$\begin{array}{c}\text { El Pertús } \\
\text { Tunnel }\end{array}$} & \multirow{2}{*}{$\begin{array}{l}\text { Undergound natural } \\
\text { gas storage (Castor) }\end{array}$} \\
\hline & $\begin{array}{c}\text { Henarsa }(\mathrm{R}- \\
2)\end{array}$ & $\begin{array}{c}\text { Accesos de } \\
\text { Madrid (R-3 } \\
\text { and (R-5) }\end{array}$ & $\begin{array}{l}\text { Madrid-Sur } \\
\text { (R-4) }\end{array}$ & Madrid-Toledo (AP-41) & & \\
\hline $\begin{array}{l}\text { Constructi } \\
\text { on firms }\end{array}$ & $\begin{array}{l}35 \% \text { ACS } \\
25 \% \text { Acciona } \\
5 \% \text { FCC }\end{array}$ & $\begin{array}{l}25 \% \text { Sacyr } \\
20 \% \text { ACS }\end{array}$ & $35 \%$ Sacyr & $\begin{array}{l}25.5 \% \text { Isolux-Corsan } \\
25.5 \% \text { Comsa-Emte } \\
17 \% \text { Azvi } \\
17 \% \text { Sando Concesiones } \\
15 \% \text { Esconcessões Latam }\end{array}$ & $\begin{array}{l}50 \% \text { ACS } \\
50 \% \text { Eiffage }\end{array}$ & $66.6 \%$ ACS \\
\hline $\begin{array}{l}\text { Industrial } \\
\text { operators }\end{array}$ & $30 \%$ Abertis $^{a}$ & $35 \%$ Abertis & $\begin{array}{l}55 \% \text { Cintra }^{\mathbf{b}} \\
(100 \% \\
\text { Ferrovial })\end{array}$ & & & $\begin{array}{l}33.3 \% \text { Castor UGS } \\
\text { Limited }^{\text {c }}\end{array}$ \\
\hline Banks & $5 \%$ Bankia & $20 \%$ Bankia & $\begin{array}{l}\text { 10\% Fondo } \\
\text { Garantía } \\
\text { Depósitos }^{\mathrm{d}}\end{array}$ & & & \\
\hline
\end{tabular}

a: Abertis is a large infrastructure operator. Two large construction firms (ACS and OHL, successively) owned up to $25 \%$ of Abertis capital throughout almost all the concession period.

b: Cintra is a large infrastructure operator that is fully owned by the large construction firm Ferrovial.

c: Castor UGS Limited Partnership is a subsidiary of Dundee Energy, who owns (74\%). Other minor investors own $26 \%$ of Castor UGS.

d: Fondo de Garantía de Depósitos is the entity created to manage funds constituted for insuring customers' bank deposits. The Bank of Spain and all banks covered by the deposit insurance participate in it.

As in other periods of Spain's infrastructure building policy, the construction of these large public works has been the business of the private sector. The profits obtained by the construction companies from the development of the infrastructure or facilities have been greater than the capital these same companies invested in the concessionaires, which was where the real risk lay.

This is clearly illustrated by the Perthus Tunnel (Figueres-Perpignan HSR line) and the Castor underwater natural gas storage projects. The cost of constructing the HSR line rose to almost $€ 1,200$ million, while the capital contributed by the two construction companies owning the concessionaire was just $€ 51$ million. In other words, a rate of return between 4 and $5 \%$ on the construction works would have matched the equity contributed. In the case of the Castor Project, the total cost of the project was more than $€ 1,600$ million, while the equity contributed by the construction firm ACS was just $€ 140$ million. In this case, a rate of return of between 8 and $9 \%$ on the construction works would have matched the equity contributed. Although the data available for the radial motorway concessions do not allow us to make such precise calculations, details on the investment costs incurred, the weight of equity in total funds, and the participation of the construction companies in each of the concessionaires present a similar picture ${ }^{15}$ to that of the Perthus Tunnel and the Castor Project.

${ }^{15}$ Based on an analysis of information available from the Spanish Government's Reports and Financial Accounts in the official registers, we have been able to establish a required rate of return on construction of between 8 and 9\% for Accesos de Madrid (R3 and R5) and Madrid Sur (R4), to compensate for the equity risk absorbed in the concessionaries by the construction companies. In the case of Henarsa (R4), the required rate of return on construction to compensate for the equity risk absorbed by the construction companies would be around $13 \%$. However, we need to be more cautious with these computations, as the data available are not as unequivocal as in the case of the Perthus Tunnel and the Castor Project. 
Note that in periods of intense economic growth (such as the one in which these projects were developed), the rate of return on large public works tends to be well over $5 \%$, and regularly over $10 \% .{ }^{16}$ For purposes of comparison, rates of return around $7 \%$ of investment costs were usual for service contracts with private partners in the case of the large infrastructure projects constructed in Spain in the early 2000s. ${ }^{17}$ Given that service contracts are free of any type of financial risk for the private partner, their rates of return tend to be lower than those of the (theoretically) riskier PPPs.

In short, the almost full financial guarantee provided by the Spanish government under PPP contracts, together with the fact that construction firms have been able to hold interests in both the construction and operation phases have been key factors in the promotion of virtually risk-free PPPs. And, as a direct result of this, these PPPs have meant huge financial liabilities for taxpayers and users.

\section{Conclusions and policy implications}

The case studies described and analyzed in this paper are not consistent with the proposition that PPPs with user pay tend to prevent white elephants. Establishing guarantees to promote participation of private firms in public projects is useful to promote PPPs, but increases the incentives for these private firms to undertake projects that are likely to end up in failure. In the very extreme case of the State' Financial Liability - as established until now in the Spanish legislation -, private firms have incentives to enter projects that will likely end up in bankruptcy in the operational phase; this, as long as the required equity is relatively low with respect to the total funds invested in the project. This it has been regularly the case in Spain. Therefore, a clear tradeoff between guarantees for private firms and prevention of white elephants is revealed.

The information and analyses reported in this study show the short-sightedness of Spain's infrastructure policies, typified by the way in which governments have promoted infrastructure projects that do not respond to demand pressures and which were riskier than usual. The government was able to use PPP contracts to develop these projects, thus avoiding internal and external $(\mathrm{EU})$ constraints designed to prevent them from incurring additional public deficit and debt.

Myopic policies resulted in myopic PPPs, in which almost all the financial risks were implicitly transferred to the taxpayers (and users), in contrast to the minimal risks faced by the private companies entering the PPP, and most significantly by the large construction companies. While contractual procedures and implementation processes may have been untroubled in the short run, in the longer term - when the concessions collapsed - the liabilities accrued for taxpayers (and consumers).

Using PPPs as eminently financial vehicles, encouraged by the comprehensive guarantees offered to the private partners and their ability to hold interests both in the construction and

16 Indeed, we cannot know rates of return on specific construction projects under concessions developed in Spain, because this information is internal to the firms, and is not available. Nonetheless, we know that by late $1990 \mathrm{~s}$, as well as throughout the $2000 \mathrm{~s}$, the regulated rate of return (legal industrial profit) for contracts of public works was set at 6\% (Art. 131.1.b of Royal Decree 1098/2001 of 12 October, developing the Law of Contracts by Public Administrations). Note that these type of 'service-contracts' do not bear relevant risks - as compared with concessions -, so its rate of return must be generally lower than that for theoretically riskier concessions.

17 This was the case, for instance, of two light rail lines built in the city of Barcelona in the first half of the last decade (Trambaix and Trambesòs), as indicated in clause 3.2 of the final version of their contract $(6.54 \%$ and $6.84 \%$, respectively). Furthermore, a rate of return of $10 \%$ was granted for operational expenses incurred by the concessionaire. 
operation of infrastructure projects, has had massive consequences for taxpayers and users. Furthermore, it has led to increasing opposition to contracting the production and delivery of public services with private partners. Indeed, the situation has undermined the public debate on how private partners might contribute to improving the delivery of public services.

In the wake of the new EU directive, the requirement that concession contracts can only be awarded when operational risk is transferred to the private partner will make it more difficult for tools such as the State's Financial Liability to be used. However, we wish to emphasize that the key challenge for public policy is to change the attitude some governments have adopted with regard to PPPs, seeing them as tools that allow them to initiate projects with highly uncertain prospects for social welfare and for which public funds are not available in the short term. However, as we have seen, these funds have been needed in the long term, and governments have been obliged to pay out even higher amounts. If government objectives and planning methods do not undergo a radical change, policy makers will continue to employ tools that allow them to pursue their own policy preferences. Further research, as well as a broader public policy debate, is clearly required to address all the issues raised here.

Acknowledgements: This research received support from the Spanish Government project ECO2016-76866-R, the Government of Catalonia - project SGR2014-325, and the School of Public Administration of Catalonia (EAPC-2014).

\section{References}

Albalate, D., 2014. The Privatisation and Nationalisation of European Roads: Success and Failure in Public-Private Partnerships. Edward Elgar, Cheltenham, UK.

Albalate, D., Álvarez, M., Bel, P., Bel, G., Esteve, M., Rosell, J., 2016. La responsabilitat patrimonial de l'administració: Motiu de sobreoferta dels partenariats públic-privats. Escola d'Administració Pública de Catalunya, Barcelona.

Albalate, D., Bel, G; Bel-Piñana, P., 2015. Tropezando dos veces con la misma piedra: Quiebra de autopistas de peaje y costes para contribuyentes y usuario. Revista de Economía Aplicada, 23(67), 131-152.

Albalate, D., Bel, G; Bel-Piñana, P; Geddes, R., 2015. Risk mitigation and sharing in motorways PPPs: A comparative policy analysis of alternative approaches. Journal of Comparative Policy Analysis, 17(5), 481-501.

Albalate, D., Bel, G; Fageda, X., 2015. When supply travels far beyond demand: Causes of oversupply in Spain's transport infrastructure. Transport Policy, 41, 80-89.

Albalate, D; Bel, G; Geddes, R., 2017. How Much Vertical Integration? Contractual Choice and Public-Private Partnerships in the United States. Review of Industrial Organization, DOI: 10.1007/s11151-016-9540-1.

Baeza, M.A; Vassallo, J.M., 2012. Traffic uncertainty in toll motorway concessions in Spain: an analysis of the ramp-up period. Transport: Proceedings of the Institution of Civil Engineers, 165, 97-105.

Bel, G., 1999. Financiación de infraestructuras viarias: La economía política de los peajes. Papeles de Economía Española, 82, 123-139.

Bel, G., 2006. Economía y política de la privatización local. Marcial Pons, Madrid, Spain.

Bel, G., 2012. Infrastructure and the Political Economy of Nation Building in Spain, 17202010. Eastbourne: Sussex Academy Press.

Bennett, J; Iossa, E., 2006. Building and Managing Facilities for Public Services. Journal of Public Economics, 90(10-11), 2143-2160.

Bradbrook, A., 2014. The law of energy underground: understanding new developments in subsurface production, transmission, and storage. Oxford University Press, Oxford. 
Cabrera, M., Suárez-Alemán, A; Trujillo, L., 2015. Public-private partnerships in Spanish Ports: Current status and future prospects. Utilities Policy, 32, 1-11.

Clifton, J., Díaz-Fuentes, D., Revuelta, J., 2014. Financing utilities: How the role of the European Investment Bank shifted from regional development to making markets. Utilities Policy, 29, 63-71.

Cruz, C.O; Marques, R.C., 2011. Contribution to the study of PPP arrangements in airport development, management and operation. Transport Policy, 18(2), 392-400.

Cruz, C.O., Marques, R.C., Cardoso, P., 2014. Empirical evidence for renegotiation of PPP contracts in the road sector. Journal of Legal Affairs and Dispute Resolution in Engineering and Construction, 7(2), DOI: 10.1061/(ASCE)LA.1943-4170.0000151

Cruz N.F; Marques, R.C., 2012. Mixed companies and local governance: No man can serve two masters. Public Administration, 90(3), 737-758.

Engel, E., Fischer, R; Galetovic, A., 2014. The economics of public-private partnerships. A basic guide. Cambridge University Press, Cambridge.

Gerring, J., 2004. What is a case study and what is it good for? American Political Science Review, 98(2), 341-354.

Gerring, J., 2007. Is there a (viable) crucial-case method? Comparative Political Studies, 40(3), 231-253.

Hodge, G.A., Greve, C; Boardman, A.E., 2010. Introduction: the PPP phenomenon and its evaluation. In Hodge, G.A; Greve, C; Boardman, A.E. (Eds.), International Handbook of Public-Private Partnerships, Edward Elgar, Cheltenham, UK, 3-16.

Iossa, E., Martimort, D., 2015. The simple microeconomics of public-private partnerships. Journal of Public Economic Theory, 17(1), 4-48.

Marques, R.C; Berg, S., 2011. Risks, contracts, and private-sector participation in infrastructure. Journal of Construction Engineering and Management, 137(11), 925932.

Marsal, J., 2014. La bombolla sísmica. Edicions Saldonar, Barcelona, Spain.

Martimort, D., Pouyet, J., 2008. To build or not to build: Normative and positive theories of public-private partnerships. International Journal of Industrial Organization, 26(2), 393-411.

Ministerio de Fomento, 2016. Informe 2015 sobre el Sector de Autopistas de Peaje en España. $\quad$ http://www.fomento.gob.es/AZ.BBMF.Web/documentacion/pdf/D050 2015.pdf (Downloaded 18h December, 2016)

Observatorio hispano-francés de tráfico en los Pirineos, 2008. Documento $\mathrm{n}^{\circ}$ 5. December 2008. Ministries of Transportation of France and Spain, 2008.

OECD, 2012. Recommendation on Principles for Public Governance of Public-Private Partnerships. OECD, Paris.

Robinson, J.A., Torvik, R., 2005. White elephants. Journal of Public Economics, 89(2/3), 197-210.

Sanz, F., 2005. Un ejemplo de concesión internacional de obras públicas: El contrato de concesión para la construcción y explotación de la línea ferroviaria a alta velocidad entre Figueras y Perpiñán. Revista de Administración Pública, 168, 381-407.

Síndic de Greuges, 2014. Informe sobre el Proyecto Castor. Noviembre 2014. Síndic de Greuges de Catalunya, Barcelona.

Vassallo, J.M., Ortega, A., Baeza, M.A., 2012. Impact of the economic recession on toll highway concessions in Spain. Journal of Management in Engineering, 28(4), 398-406.

WB, 2015. Report on recommended PPP contractual provisions. 2015 edition. World Bank Group, Washington DC.

Yin, R.K., 1984. Case study research: design and methods. Sage, Newbury Park (CA) 